\title{
Changes of lipids during therapy with atorvastatin in middle age women with different genetic polymorphisms of estradiol receptors
}

\author{
Isayeva G A nna ${ }^{*}$, Martynenko Alexander ${ }^{2}$, Vovchenko Maryna ${ }^{1}$, Bondar Tatyana ${ }^{1}$ and Ostropolets Sergii ${ }^{2}$ \\ ${ }^{1}$ The Government Institution "National Institute of Therapy named by L.T. Malaya of National Ukrainian Academy of Medical Science”, Kharkov, Ukraine \\ ${ }^{2}$ Kharkiv National University named after V. N. Karazin, Ukraine
}

\section{Introduction}

Estrogens play important role in the regulation of lipids metabolism [1]. It has been established that estradiol promotes the increase in quantity of low density lipoprotein receptors on hepatocytes [2-4]. Besides, estradiol is capable to decrease the activity of 3-methylglutarylcoenzyme A reductase [5] and increase reverse cholesterol transport [6]. Physiological effects of estradiol are realized via genomic and nongenomic pathways. Genomic effects are mediated via specific receptors: estrogen receptors alpha (ESR $\alpha$ ) and estrogen receptors beta (ESR $\beta$ ) [7]. ESR genetic polymorphism has been established to be associated with several diseases: breast cancer, Alzheimer's disease, arterial hypertension [8-10]. Equivocal data regarding the relation between polymorphism of estradiol receptors and atherosclerosis onset risk and course are available in literature [11-13]. Carrying of some locii may modify the coronary artery disease risk related to high endogenous estrogens levels in older postmenopausal women. Hypercoagulability may act as a mediator [14]. Several studies have demonstrated the relation between carriage of certain ESR a polymorphisms and lipid metabolism disorders $[12,15,16]$. The above facts turn alpha type estradiol receptors into an interesting target for the study of statins hypolipidemic effect.

The goal of the present study was investigation of the relation between carriage of polymorphic loci of genes encoding estradiol receptor synthesis and atorvastatin hypolipidemic effect in middle age women with coronary heart disease.

\section{Methods}

Study patient cohort:147 female patients with coronary heart disease with median age $54.2(49.0 \div 59.0)$ years old participated in this study.

Lipid analysis: Plasma lipids levels were determined in venous blood samples obtained after 9 hours fast. Total cholesterol, triglycerides and cholesterol of high density lipoproteins were determined by enzyme methods (Cormay, Poland). Cholesterol of low density lipoproteins was calculated using Friedewald formula [17].

DNA amplification and genotyping analysis: Leukocytes of peripheral blood from female patients were used as the material for molecular and genetic research. Peripheral blood was obtained by blood sampling from cubital vein in the fasting condition into a vacuum EDTO tube. DNA genome extraction from whole blood was performed using commercial set called DNA-sorb-B (Amplisens, RF) according to manufacturer's instructions.

Polymorphous segment XbaI (rs9340799; A/G; xx/XX) alleles in ESR1 gene were determined by PCR method using Tercyc amplifier (DNA technology) with subsequent analysis of restriction fragment length polymorphism by electrophoresis method. Variable DNA sections were amplified on PCR-ready mixture, GenePak PCR Core (IsoGene Laboratory).ESR1 gene DNA fragment amplification products were subject to hydrolytic disintegration using XbaI endonuclease restriction (manufactured by Thermo Scientific). Amplification and restriction products were detected by electrophoresis in $2.5 \%$ agarose gel (Helikon) for 1 hour at electric field strength of $5 \mathrm{~V} / \mathrm{cm}$ of gel. DNA fragments were visualized using: ultraviolet irradiator (ECX15.M) with the wavelength of $312 \mathrm{~nm}$, GEL IMAGER 2 videosystem (Bioclone SPF) and GEL EXPLORER software. As DNA molecular mass marker, GeneRuler 100bp Plus DNA Ladder was used (Thermo Scientific, Lithuania).

ESR1 gene polymorphism genotypes were identified by the length of fragments (n.p.) obtained in the result of restriction:

- AA (971 n.p. + 381 n.p.), AG (1352 n.p. + 971 n.p. + 381 n.p.), GG (1352 n.p.) (Figure 1 and 2).

Therapy: Women were treated with $40 \mathrm{mg}$ of atorvastatin. Nebivolol was used in all groups to control blood pressure and heart rate. Aspirin, $75 \mathrm{mg}$, was prescribed to all.

Statistical analysis: Statistical analysis was performed with SPSS software, version.

\section{Results}

Prevalence of genotypes and alleles of the test loci in patients included to the study is shown in Table 1.

Correspondence to: Isayeva G Anna, The Government Institution "National Institute of Therapy named by L.T. Malaya of National Ukrainian Academy of Medical Science", Kharkov, Ukraine, Tel: +380504006550; Fax: +380577701538; E-mail: anna_isayeva_74@yahoo.co.uk

Keywords: estrogens; lipids metabolism; genetic polymorphism; hypolipidemic effect

Received: September 12, 2016; Accepted: October 07, 2016; Published: October 13,2016 
Table 2 represents comparison of patient groups with certain variants of polymorphic loci XbaI and PvuII. The groups had no significant differences in terms of age, BMI, and number of patients with essential hypertension and diabetes mellitus.

Reliable decrease in total cholesterol and LDL cholesterol levels has been established to occur in patient groups with AG \& GG genotypes of polymorphic locus XbaI, and TC \& CC genotypes of polymorphic locus PvuII. Patients with AA genotype of polymorphic locus XbaI and CC genotype of polymorphic locus PvuII showed no statistically significant decrease in these parameters (Table 3 ).

The highest number of women achieving the target LDL cholesterol ( $\leq 1.8 \mathrm{mmol} / \mathrm{l}$ ) [18] level belonged to the group with GG genotype.

In view of the fact that response to statin therapy may differ in case of various genotype combinations of polymorphic genes XbaI and PvuII, we carried out a search of genotype combination for which the response to atorvastatin therapy in terms of LDL would be the most and the least pronounced. We have established that, in the case of combination of AA genotype of polymorphic gene $\mathrm{XbaI}$ with any genotype variant of polymorphic gene PvuII, the decrease of LDL cholesterol level has no statistical significance. Paired Student t-test shows the absence of

Table 1. Genotype and alleles distribution.

\begin{tabular}{|c|c|c|c|}
\hline \multicolumn{4}{|l|}{ ESR1 XbaII } \\
\hline $\mathrm{AA}$ & $\mathrm{AG}$ & GG & $p$ \\
\hline $63(42,0 \%)$ & $66(44,0 \%)$ & $21(14,0 \%)$ & $\begin{array}{l}\mathrm{p}_{1-2}=0.68 \\
\mathrm{p}_{1-3}=0.51 \\
\mathrm{p}_{2-3}=0.71\end{array}$ \\
\hline \multicolumn{4}{|l|}{ ESRI PvuII } \\
\hline TT & $\mathrm{TC}$ & $\mathrm{CC}$ & \\
\hline $36(24,0 \%)$ & $92(62,0 \%)$ & $22(14,0 \%)$ & $\begin{array}{l}\mathrm{p}_{1-2}=0.72 \\
\mathrm{p}_{1-3}=0.20 \\
\mathrm{p}_{2-3}=0.07\end{array}$ \\
\hline
\end{tabular}

Table 2. Genotype distribution of estrogen receptors and characteristic of the patient's groups.

\begin{tabular}{|c|c|c|c|c|}
\hline & \multicolumn{3}{|c|}{ Genotypes } & \multirow[t]{3}{*}{$p$} \\
\hline \multicolumn{4}{|l|}{ ESRI XbaII } & \\
\hline & $\mathrm{AA}(\mathrm{n}=63)$ & $\mathrm{AG}(\mathrm{n}=66)$ & $\mathrm{GG}(\mathrm{n}=21)$ & \\
\hline Age, years & $55,0(49,0 \div 61,0)$ & $56,0(49,0: 61,0)$ & $56,0(51,0: 58,0)$ & $\begin{array}{l}\mathrm{p}_{1-2}=0.95 \\
\mathrm{p}_{1-3}=0.50 \\
\mathrm{p}_{2-3}=0.41\end{array}$ \\
\hline $\begin{array}{l}\text { Body mass index, } \\
\mathrm{kg} / \mathrm{m}^{2}\end{array}$ & $28.8(27.0 \div 31.9)$ & $29.0(25.5 \div 34.1)$ & $29.2(27.0 \div 33.5)$ & $\begin{array}{l}\mathrm{p}_{1-2}=0.83 \\
\mathrm{p}_{1-3}=0.64 \\
\mathrm{p}_{2-3}=0.70\end{array}$ \\
\hline $\begin{array}{l}\text { Hypertension, } \\
\mathrm{n}(\%)\end{array}$ & $48(76.2 \%)$ & $50(75.8 \%)$ & $15(71.4 \%)$ & $\begin{array}{l}\mathrm{p}_{1-2}=0.95 \\
\mathrm{p}_{1-3}=0.66 \\
\mathrm{p}_{2-3}=0.69\end{array}$ \\
\hline $\begin{array}{l}\text { Diabetes mellitus, } \\
\mathrm{n}(\%)\end{array}$ & $9(14.2 \%)$ & $9(13.6 \%)$ & $2(9.5 \%)$ & $\begin{array}{l}\mathrm{p}_{1-2}=0.92 \\
\mathrm{p}_{1-3}=0.58 \\
\mathrm{p}_{2-3}=0.62\end{array}$ \\
\hline \multicolumn{5}{|l|}{ ESRI PvuII } \\
\hline & $\mathrm{TT}(\mathrm{n}=36)$ & $\mathrm{TC}(\mathrm{n}=92)$ & $\mathrm{CC}(\mathrm{n}=22)$ & \\
\hline Age, years & $55,0(49.0 \div 60,0)$ & $52.0(47.0 \div 58.0)$ & $55,0(52.0 \div 61.0)$ & $\begin{array}{l}\mathrm{p}_{1-2}=1.00 \\
\mathrm{p}_{1-3}=0.36 \\
\mathrm{p}_{2-3}=0.13\end{array}$ \\
\hline $\begin{array}{l}\text { Body mass index, } \\
\mathrm{kg} / \mathrm{m}^{2}\end{array}$ & $28.9(26.4 \div 31,8)$ & $29.0(26.6 \div 32.0)$ & $29.1(26.3 \div 33.5)$ & $\begin{array}{l}\mathrm{p}_{1-2}=0.89 \\
\mathrm{p}_{1-3}=0.86 \\
\mathrm{p}_{2-3}=0.97\end{array}$ \\
\hline $\begin{array}{l}\text { Hypertension, } \\
\mathrm{n}(\%)\end{array}$ & $26(72.2 \%)$ & $71(77.2 \%)$ & $11(66.6 \%)$ & $\begin{array}{l}\mathrm{p}_{1-2}=0.56 \\
\mathrm{p}_{1-3}=0.08 \\
\mathrm{p}_{2-3}=0.01\end{array}$ \\
\hline $\begin{array}{l}\text { Diabetes mellitus, } \\
\mathrm{n}(\%)\end{array}$ & $6(16,6 \%)$ & $10(10,8 \%)$ & $1(4,54 \%)$ & $\begin{array}{l}\mathrm{p}_{1-2}=0,37 \\
\mathrm{p}_{1-3}=0,17 \\
\mathrm{p}_{2-3}=0,37\end{array}$ \\
\hline
\end{tabular}

reliable difference between LDL parameters before and after therapy in the event AA genotype is combined with any of the variants of Pvull genotypes. Thus, median LDL at the baseline comprised $3.38(2.91 \div$ 4.00 ), and the same following therapy was equal to $3.10(2.32 \div 4.40)$, $\mathrm{p}=0.11$ (Figure 2).

Reliable decrease in LDL cholesterol levels has been identified in the event of combination of GG genotype with any of the variants of polymorphic locus Pvull (CC, TT, TC). Thus, median LDL at the baseline was $4.06(3.59 \div 3.34) \mathrm{mmol} / \mathrm{l}$, and the same after therapy was $2.05(1.80 \div 2.45) \mathrm{mmol} / \mathrm{l}, \mathrm{p}=0.0008$ (Figure 3 ).

Study of the effects of gene Xbal heterozygous variant has shown

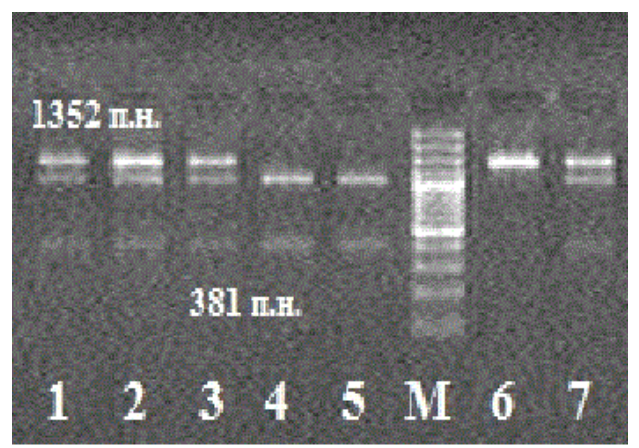

Figure 1. Electrophoregram of restriction products in ESR1 gene polymorphism analysis. Note: Samples 1-3, 7 are genotype AG carriers; $M$ is the DNA molecular mass marker; samples 4-5 are AA genotype carriers; sample 6 is GG genotype carrier.

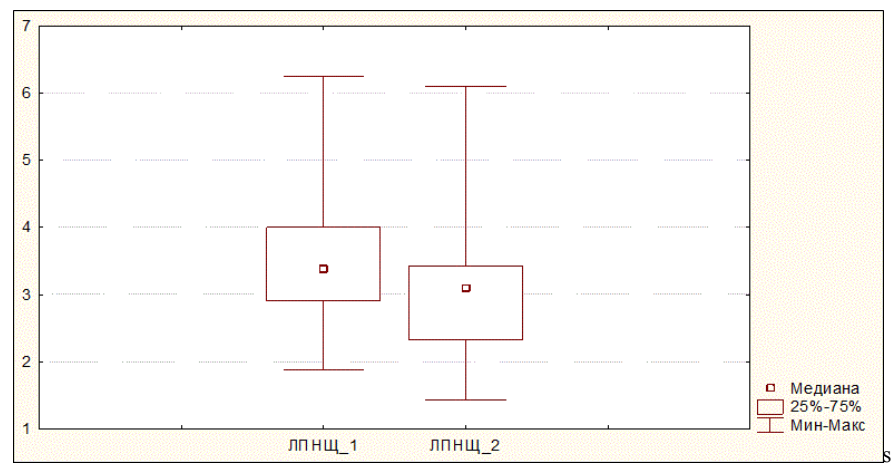

Figure 2. Change of LDL cholesterol levels during atorvastatin therapy in the event of combined carriage of AA genotype and any of genotypes of polymorphic gene PvuII (TC, TT or $\mathrm{CC}$ ).

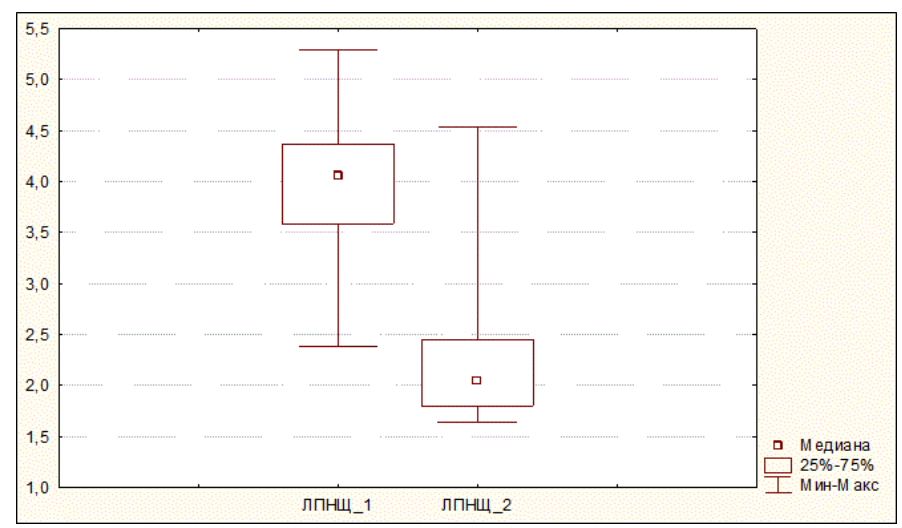

Figure 3. Change of LDL cholesterol levels during atorvastatin therapy in the event of combined carriage of GG genotype and any of genotypes of polymorphic gene PvuII (TC, TT or CC). 
that combined carriage of AG genotype with any of the variants of polymorphic gene PvuII (TC, TT or CC) is manifested by essential, statistically reliable decrease in LDL cholesterol (Figure 4).

\section{Discussion}

It is worth mentioning that, in gene pair XbaI and PvuII, the first gene most probably has higher value for prediction of atorvastatin effect on LDL cholesterol level. This conclusion can be drawn from the fact that an attempt to isolate any variant of PvuII genotype of critical importance for cholesterol lowering did not reveal any significant differences between the groups.

Therefore, the data obtained allow concluding the presence of relation between LDL cholesterol dynamics during atorvastatin therapy and carriage of certain variants of polymorphic genes XbaI и PvuII. Thus, the patients - GG and AG genotype carriers show more pronounced LDL cholesterol decrease during atorvastatin therapy. The most unfavorable results of atorvastatin therapy are noticed in AA genotype carriers. Thus, the combination of AA genotype with any of genotypes of PvuII polymorphic gene is characterized by unreliable LDL cholesterol decrease as affected by atorvastatin.

Estradiol capability to affect cholesterol metabolism is beyond any doubt. Relatively high portion of these effects is mediated through estradiol receptors currently found in hepatocytes, myocardium, and vascular wall. Thus, estrariol receptors represent an essential regulatory link in realization of "lipid" effect of the hormone itself. Two types of estradiol receptors are classified: estradiol $\alpha$-receptors (ESR $\alpha$ ) and $\beta$-receptors $(\operatorname{ESR} \beta)$. ESR $\alpha$ receptors are believed to play a more important role in realization of estradiol cardiovascular biological effects. ESRa is located on chromosome 6-q (locus 6q24-q27) and includes 8 exons and 6 introns. Presence of two polymorphisms in the first intron: PvuII, also known as rs2234693, and XbaI known as rs9340799, is of special importance. PvuII and XbaI polymorphism may affect transcription of ESR1 gene and alter its splicing.

Many authors have shown the relation between the presence of these polymorphisms, lipid metabolism disorders, LDL and HDL changes during hormone replacement therapy, CHD development risk and the disease course. Thus, the relation between PvuII polymorphism and CHD development has been shown in Chinese population. At the same time, no relation between myocardial infarction development risk and this polymorphism has been identified in European population. Based on meta-analysis of 21 studies including in total $9926 \mathrm{CHD}$ patients and 16710 healthy individuals, Ding J has shown that PvuII polymorphism is essential for CHD development in Eastern regions, but its role is not that essential for Western nationalities. Prevalence of stenoses in a stent following stenting has been shown to be higher in female patients homozygous by $\mathrm{T}$ allele. Carriers of $\mathrm{G}$ allele of polymorphic gene XbaI either in homozygous or heterozygous variant have higher levels of diastolic blood pressure, LDL cholesterol, and HOMA index. At the same time, no coronary artery damage confirmed by angiography and XbaI polymorphism has been detected in Iranian population. Alevizaki $\mathrm{M}$ et al., and $\mathrm{Lu} \mathrm{H}$ et al. $[8,13]$ relate $\mathrm{CHD}$ severity and early CHD development risk with XbaI polymorphism as well. Nevertheless, Boroumand $\mathrm{M}$ et al. [16] have not identified any relation between either PvuII or XbaI polymorphism and lipid profile, as well as inflammation markers in women. Inconsistency of the results can be explained by the use of different CHD verification methods, as well as relatively heterogeneous patient groups, by the authors. Besides, CHD itself is characterized by polyetiology and complicated pathogenesis mechanisms; the role of estradiol receptors is not limited only to their

Table 3. Changes of lipids in the group with different genotypes.

\begin{tabular}{|c|c|c|c|c|c|c|c|}
\hline \multicolumn{8}{|l|}{ ESR1 XbaII } \\
\hline & & AA & $\mathrm{p}$ & $\mathrm{AG}$ & $\mathrm{p}$ & GG & $\mathrm{p}$ \\
\hline \multirow[t]{2}{*}{ Total cholesterol, mmol/l } & Before therapy & $5.20(4.54 \div 5.75)$ & \multirow[t]{2}{*}{0.91} & $5,35(4,56 \div 6,26)$ & \multirow[t]{2}{*}{0.02} & $\begin{array}{c}5.72 \\
(5.26 \div 6.16)\end{array}$ & \multirow[t]{2}{*}{0.04} \\
\hline & six-month therapy & $5.30(4.30 \div 6.08)$ & & $4,96(4.40 \div 5.85)$ & & $4,90(4.01 \div 5.21)$ & \\
\hline \multirow[t]{2}{*}{ Triglycerides, mmol/1 } & Before therapy & $1,20(0,90 \div 1,60)$ & \multirow[t]{2}{*}{0.14} & $1.23(0.97 \div 1,73)$ & \multirow[t]{2}{*}{0.12} & $1,10(0.93 \div 1.24)$ & \multirow[t]{2}{*}{0.65} \\
\hline & six-month therapy & $1.17(0.90 \div 1.48)$ & & $1.17(0.70 \div 1.62)$ & & $1.08(0.91 \div 1.21)$ & \\
\hline \multirow[t]{2}{*}{ LDL cholesterol, mmol/1 } & Before therapy & $3.18(2.57 \div 3.80)$ & \multirow[t]{2}{*}{0.12} & $3.24(2.48 \div 4.21)$ & \multirow[t]{2}{*}{0.02} & $3.80(3.28 \div 4.13)$ & \multirow[t]{2}{*}{0.01} \\
\hline & Six-month therapy & $3.14(2.30 \div 3,41)$ & & $2.40(1.80 \div 3,00)$ & & $2.02(1.80 \div 2.45)$ & \\
\hline \multirow[t]{2}{*}{ HDL cholesterol, mmol/1 } & Before therapy & $1.34(1.16 \div 1.71)$ & \multirow[t]{2}{*}{0.06} & $1.42(1.15 \div 1,62)$ & \multirow[t]{2}{*}{0.28} & $1.46(1.30 \div 1.68)$ & \multirow[t]{2}{*}{0.03} \\
\hline & six-month therapy & $1.50(1.20 \div 1.90)$ & & $1.47(1.20 \div 1.90)$ & & $1.61(1.30 \div 1.90)$ & \\
\hline \multicolumn{8}{|l|}{ ESRI PvuII } \\
\hline & & TT & & $\mathrm{TC}$ & & $\mathrm{CC}$ & \\
\hline \multirow[t]{2}{*}{ Total cholesterol, mmol/l } & Before therapy & $5.01(4.48 \div 5.58)$ & \multirow[t]{2}{*}{0.89} & $5.36(4.78 \div 6.17)$ & \multirow[t]{2}{*}{0.002} & $5.68(4.90 \div 6.12)$ & \multirow[t]{2}{*}{0.05} \\
\hline & six-month therapy & $5.00(4.23 \div 5.92)$ & & $5.07(4.51 \div 5.90)$ & & $4.90(4.12 \div 5.32)$ & \\
\hline \multirow[t]{2}{*}{ Triglycerides, mmol/1 } & Before therapy & $1.20(0.86 \div 1,67)$ & \multirow[t]{2}{*}{0.07} & $1.35(1.01 \div 1.73)$ & \multirow[t]{2}{*}{0.14} & $1.05(0.84 \div 1.25)$ & \multirow[t]{2}{*}{0.53} \\
\hline & six-month therapy & $1.12(0,90 \div 1,37)$ & & $1.15(0.78 \div 1.70)$ & & $1.08(0.83 \div 1.21)$ & \\
\hline \multirow[t]{2}{*}{ LDL cholesterol, mmol/1 } & Before therapy & $3.03(2,43 \div 3,71)$ & \multirow[t]{2}{*}{0.10} & $3.33(2.48 \div 4.08)$ & \multirow[t]{2}{*}{0.002} & $3.69(2.93 \div 4.17)$ & \multirow[t]{2}{*}{0.02} \\
\hline & six-month therapy & $2.55(2.10 \div 3.43)$ & & $2.60(1.90 \div 3.20)$ & & $2.15(1.80 \div 2.70)$ & \\
\hline \multirow[t]{2}{*}{ HDL cholesterol, mmol/1 } & Before therapy & $1.34(1.19 \div 1,49)$ & \multirow[t]{2}{*}{0.04} & $1.37(1.14 \div 1.62)$ & \multirow[t]{2}{*}{0,13} & $1,47(1.34 \div 1,62)$ & \multirow[t]{2}{*}{0.46} \\
\hline & six-month therapy & $1.50(1.20 \div 1.90)$ & & $1.40(1.20 \div 1,90)$ & & $\begin{array}{c}1,60 \\
(1.50 \div 1.81)\end{array}$ & \\
\hline
\end{tabular}

Table 4. Number of patients achieving the target LDL cholesterol level.

\begin{tabular}{|l|c|c|c|}
\hline & AA (n= 63) & AG (n= 66) & GG (n= 21) \\
\hline Number of patients achieving the target LDL cholesterol level, n (\%) & $36(57.1 \%)$ & $51(77,3 \%)$ & $19(90,5 \%)$ \\
\hline Number of patients achieving the target LDL cholesterol level, n (\%) & TT (n=36) & TC $(\mathrm{n}=92)$ & $\mathrm{CC}(\mathrm{n}=22)$ \\
\hline
\end{tabular}


relation with lipid metabolism, but also includes their participation in thrombosis, endothelial function disorders, and other mechanisms. The fact requiring explanations is the presence of relation between carriage of PvuII/XbaI gene polymorphisms in Eastern populations and their absence in the Western ones. In this case, we have identified the association between atorvastatin hypolipidemic effect and carriage of XbaI locus polymorphisms in Ukrainian population.

No studies of relation between different variants of polymorphic genes PvuII/XbaI and the change of lipid metabolism parameters during statin therapy were conducted previously. The work performed allows suggesting that carriers of GG genotype of XbaI polymorphic locus are more susceptible to atorvastatin therapy.

Study limitations. The study was conducted in a limited patient cohort. The hypothesis was not tested in women of elderly age groups.

\section{References}

1. Crandall CJ, Barrett-Connor E (2013) Endogenous sex steroid levels and cardiovascular disease in relation to the menopause: a systematic review. Endocrinol Metab Clin North Am 42: 227-253. [Crossref]

2. Shchelkunova TA, Morozov IA, Rubtsov PM, Samokhodskaya LM, Andrianova IV, et al. (2013) Effect of sex hormones on levels of mRNAs coding for proteins involved in lipid metabolism in macrophages. Biochemistry (Mosc) 78: 1342-1353. [Crossref]

3. Ngo Sock ET, Chapados NA, Lavoie JM (2014) LDL receptor and Pcsk9 transcripts are decreased in liver of ovariectomized rats: effects of exercise training. Horm Metab Res 46: 550-555. [Crossref]

4. Uebi T, Umeda M, Imai T (2015) Estrogen induces estrogen receptor alpha expression and hepatocyte proliferation in the livers of male mice. J Genes Cells 20: 217-223.

5. De Marinis E, Martini C, Trentalance A, Pallottini V (2008) Sex differences in hepatic regulation of cholesterol homeostasis. J Endocrinol 198: 635-643. [Crossref]

6. Zanotti I, Favari E, Bernini F (2012) Cellular cholesterol efflux pathways: impact on intracellular lipid trafficking and methodological considerations. $J$ Current Pharmaceutical Biotechnology 13: 292-302.

7. Khalil RA (2013) Estrogen, vascular estrogen receptor and hormone therapy in postmenopausal vascular disease. J Biochemical Pharmacology 86: 627-642.
8. Lu H, Chen D, Hu LP, Zhou LL, Xu HY, et al. (2014) Estrogen receptor alpha gene polymorphisms and breast cancer risk: a case-control study with meta-analysis combined. Asian Pac J Cancer Prev 14: 6743-6749. [Crossref]

9. Figtree GA, Noonan JE, Bhindi R (2009) Estrogen receptor polymorphisms significance to human physiology, disease and therapy. J Recent Patents on DNA \& Gene Sequences 3: 164-171.

10. Cheng D, Liang B, Hao Y, Zhou W (2014) Estrogen receptor $\hat{I} \pm$ gene polymorphisms and risk of Alzheimer's disease: evidence from a meta-analysis. Clin Interv Aging 9: 1031-1038. [Crossref]

11. Jiang N, Yang G, Peng CL (2015) ESR1 gene polymorphisms PvuII (rs2234693T >C) and XbaI (rs9340799A $>$ G) may not be directly correlated with cardiovascular disease risk. Genet Mol Res 14: 13932-13944. [Crossref]

12. Ding J, Xu H, Yin X, Zhang FR, Pan XP, et al. (2014) Estrogen receptor $\hat{I} \pm$ gene PvuI polymorphism and coronary artery disease: a meta-analysis of 21 studies. $J$ Zhejiang Univ Sci B 15: 243-255. [Crossref]

13. Alevizaki M, Saltiki K, Cimponeriu A, Kanakakis I, Xita N, et al. (2007) Severity of cardiovascular disease in postmenopausal women: associations with common estrogen receptor alpha polymorphic variants. Eur J Endocrinol 156: 489-496. [Crossref]

14. Scarabin-Carré V, Brailly-Tabard S, Ancelin ML (2014) Plasma estrogen levels, estrogen receptor gene variation, and ischemic arterial disease in postmenopausa women: the three-city prospective cohort study. J Clin Endocrinol Metab 99: 15391546 .

15. Shen C, Chen J, Fan S, Li Z, Hu Y, et al. (2012) Association between the polymorphism of estrogen receptor $\hat{\mathrm{I}} \pm$ and coronary artery disease in a Chinese population. Eur $J$ Intern Med 23: 175-178. [Crossref]

16. Boroumand M, Ghaedi M, Mohammadtaghvaei N, Pourgholi L, Anvari MS, et al (2009) Lipid profile and inflammatory markers associated with estrogen receptor alpha PvuII and XbaI gene polymorphisms. Transl Res 153: 288-295. [Crossref]

17. Friedewald WT, Levy RI, Fredrickson DS (1972) Estimation of the concentration of low-density lipoprotein cholesterol in plasma, without use of the preparative ultracentrifuge. Clin Chem 18: 499-502. [Crossref]

18. Task Force Members, Montalescot G, Sechtem U, Achenbach S, Andreotti F, et al (2013) 2013 ESC guidelines on the management of stable coronary artery disease the Task Force on the management of stable coronary artery disease of the European Society of Cardiology. Eur Heart J 34: 2949-3003. [Crossref]

Copyright: (C2016 Anna IG. This is an open-access article distributed under the terms of the Creative Commons Attribution License, which permits unrestricted use, distribution, and reproduction in any medium, provided the original author and source are credited. 